\title{
Comparison of the direct enzyme assay method with the membrane filtration technique in the quantification and monitoring of microbial indicator organisms - seasonal variations in the activities of coliforms and $E$. coli, temperature and $\mathrm{pH}$
}

\author{
VC Wutor, CA Togo and BI Pletschke* \\ Department of Biochemistry, Microbiology and Biotechnology, Rhodes University, PO Box 94, Grahamstown 6140, South Africa
}

\begin{abstract}
The aim of this project was to monitor variations and relationships between coliform and $E$. coli counts, the activities of their marker enzymes GAL and GUD, and temperature and $\mathrm{pH}$ over a period of 12 months in river samples obtained from the Eastern Cape, South Africa. Several polluted water samples were collected for direct coliform $\beta$-D-galactosidase (B-GAL) and Escherichia coli $\beta$-D-glucuronidase (B-GUD) assays and the membrane filtration technique. While all the samples showed enzyme activities, not all exhibited growth on CM1046 media. Variation in B-GAL activity (40\%) was observed between November (highest activity month) and May (lowest activity month). The highest and lowest B-GUD activities were observed in the months of September and May/June, respectively. The sensitivity of the spectrophotometric assay method was indicated by a limit of detection (LOD) of 1 coliform forming unit (CFU)/100 $\mathrm{m} \ell$ and $2 \mathrm{CFU} / 100 \mathrm{~m} \ell$ for coliforms and E. coli, respectively. There was a significant $(\mathrm{P}<0.05)$ positive correlation between $\mathrm{E}$. coli counts and GUD activity $\left(\mathrm{R}^{2}=0.8909\right)$. A correlation of $\mathrm{R}^{2}=0.9151$ was also observed between total coliforms and B-GAL activity, even though the CFUs were not evenly distributed. Direct enzyme assays were also shown to be more sensitive than the membrane filtration (MF) technique.
\end{abstract}

Keywords: chlorophenol red $\beta$-D-galactopyranoside (CPRG), chlorophenol red (CPR), coliforms, E. coli, $p$-nitrophenyl- $\beta$-D-glucuronide (PNPG), $p$-nitrophenyl (PNP)

\section{Introduction}

Coliform bacteria have the ability to produce the enzyme $\beta$-Dgalactosidase (B-GAL) while Escherichia coli produce $\beta$-D-glucuronidase (B-GUD). These two enzymes have been used as selective markers for coliforms and E. coli respectively in the water quality industry for over 100 years. The enzymes hydrolyse a wide range of chromogenic and fluorogenic substrates yielding products which can be monitored spectrophotometrically or fluorometrically.

The traditional techniques of detecting and enumerating these micro-organisms require up to $72 \mathrm{~h}$ to perform. This required time is too long to provide useful information about a decrease in water quality that may require immediate attention to protect the public (Berg and Fiksdal, 1988). One other major limitation with the traditional methods is the inability to detect viable but non-culturable bacterial cells (VBNC). As a result, direct enzyme assays, which are faster and not limited by VBNC cells, have become popular amongst water quality scientists.

Each enzyme has a characteristic optimum $\mathrm{pH}$ and temperature requirement. Similar enzymes, but from different environments, can have different $\mathrm{pH}$ and temperature optima. $\mathrm{pH}$ plays an important role in the activity of enzymes. It affects the structural stability and solubility of, as well as the charge and charge distribution on both enzymes and substrates (Holme and Peck, 1998). These factors, in turn, alter bonds and bonding patterns, ultimately determining the rate of the enzyme-catalysed reaction.

\footnotetext{
* To whom all correspondence should be addressed.

용 +27 46 603-8081; fax: +27 46 622-3984;

e-mail:B.Pletschke@,ru.ac.za

Received 21 July 2006; accepted in revised form 5 October 2006.
}

Temperature also influences the rate of molecular collision and bond vibrations. An increase in temperature (usually up to $40^{\circ} \mathrm{C}$ ) increases the number of collisions between substrates and enzymes, hence increasing the reaction rates. Increased bond vibrations due to an increase in temperature leads to bond disruptions that can facilitate easy and rapid substrate breakdown. However, this bond disruption will also cause denaturation of the enzymes themselves. As a result, temperature optimum will be a compromise between maximum activity and enzyme denaturation (Holme and Peck, 1998).

The use of the direct enzyme assay technique on environmental water samples thus presents a very complex situation as there may be compounds in the environment which may react to either increase or inhibit the activities of the enzymes. The effect of temperature and $\mathrm{pH}$ variations as a result of seasonal changes may also influence enzyme activities.

The two major objectives of this study were to compare the direct enzyme assay with the MF technique in quantifying microbial indicator organisms and to monitor variations in the activities of coliforms and $E$. coli throughout a 12-month cycle. Temperature and $\mathrm{pH}$ changes were also studied due to their effects on enzyme activity.

\section{Materials and methods}

\section{Materials}

Chlorophenol red $\beta$-D-galactopyranoside (CPRG), disodium hydrogen phosphate, dihydrogen sodium phosphate were all obtained from Merck (Darmstadt, Germany). The buffers were prepared using water purified with a Milli-Q system (Millipore, Milford, CT, USA). All reagents were of the highest analytical grade available. 


\section{Sampling}

Water collection was performed in accordance with the standard procedures outlined in Standard Methods (1989). Water samples were collected from the Bloukrans River, Grahamstown in the Eastern Cape of South Africa. Samples were collected aseptically in $250 \mathrm{~m} \ell$ sterile Pyrex glass bottles (Schott Duran, Germany), placed on ice and transported immediately to the laboratory and analysed within an hour. Two sampling points; stagnant and running, were selected. Samples were collected in triplicate between 08:00 and 08:30 on each sampling morning.

\section{Methods}

\section{B-GAL enzyme assay}

The B-GAL assay was performed according to the protocols of Seeber and Boothroyd (1996) and Pelisek et al. (2000) with modification. CPRG ( $80 \mu \mathrm{g}$ in $20 \mu \ell$ water) was added to $90 \mu \ell 0.1 \mathrm{M}$ sodium phosphate buffer ( $\mathrm{pH} 7.8$ ), and $90 \mu \ell$ of environmental (water) sample was added to initiate the reaction. The change in absorbance was monitored at $575 \mathrm{~nm}$ over $24 \mathrm{~h}$ on a PowerWave (Bio-Tek Instruments, USA).

\section{B-GUD enzyme assay}

PNPG (10 mM) (Calbiochem (Merck, Darmstadt, Germany) was prepared in the assay buffer $(0.1 \mathrm{M}$ Tris- $\mathrm{HCl}, \mathrm{pH} 8.0$ containing $0.6 \mathrm{mM} \mathrm{CaCl}_{2}$ ). The standard PNPG assay was adapted from Fisher and Woods (2000) and Aich et al. (2001). Assay buffer $(50 \mu \ell)$ and $90 \mu \ell$ enzyme solution/water sample were mixed in a $96-$ well, flat-bottomed micro-titre plate. The reaction was initiated by the addition of $110 \mu \ell$ PNPG. Kinetic readings $\left(24 \mathrm{~h}\right.$ at $1 \mathrm{~h}$ intervals) were performed at $405 \mathrm{~nm}$ and $25^{\circ} \mathrm{C}$ using

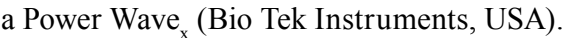

In each enzyme assay, two sets of controls were set up; an enzyme control and a substrate control. All readings were taken against milli-Q water (Millipore Corporation, USA). All assays were performed in triplicate, unless otherwise stated. All results are reported as means \pm standard deviations.

B-GAL and B-GUD activities from the two sampling points were determined weekly for a period spanning over 12 months. Monthly results were averaged and a graph of percentage relative mean monthly activity vs. month of the year was constructed.

\section{Microbiological analyses}

Water sample volumes of $100 \mathrm{~m} \ell$ were filtered through membrane filters (Whatman $0.45 \mu \mathrm{m}$ pore size) and placed on $\mathrm{CM}$ 1046 media (selective E. coli/Coliform Chromogenic Medium) (Oxoid) and incubated at $37^{\circ} \mathrm{C}$ for $24 \mathrm{~h}$, after which colonies were counted. All colonies which developed a pink colour were counted as coliforms while those that developed a purple colour were counted as $E$. coli. These were then expressed as coliform colony-forming units (CFU) per $100 \mathrm{~m} \ell$.

\section{Temperature and $\mathrm{pH}$ studies}

Weekly temperature and $\mathrm{pH}$ were also measured over the oneyear study period. The temperature of the water samples was determined on site and the $\mathrm{pH}$ determined upon arrival in the laboratory.

\section{Regression studies and comparison with the MF technique}

Water samples were collected from different environments in the Eastern Cape area (river mouths of Kariega, Bushmans and Sundays Rivers, a marshy area around the Swartkops Estuary near Port Elizabeth (PE), final effluent from PE wastewater treatment plant, marine environment and freshwater bodies around Grahamstown)

Microbial counts by membrane filtration (MF), as outlined by Farnleitner et al. (2001), were adapted and performed on Oxoid CM 1046. Direct B-GAL and B-GUD activities were also determined on the samples. From these data sets, a comparison of the direct enzyme assay methods and MF procedure on CFU determination was performed to assess the efficiency and applicability of each of these two methods. From the regression curves, the LOD (limit of detection) was determined.

\section{Results and discussions}

The source of coliforms in this study was confirmed as $E$. coli through tryptic mapping of bands observed on SDS-PAGE and MALDI-TOF and subsequent bio-informatic analysis (data not shown).

\section{Monthly (seasonal) trends}

Generally, the June to August period (winter months) exhibited low enzyme activity (Figs. $1 \& 2$ ). The highest GUD activity was observed in September (Fig. 2). The GUD trend exhibited three peak periods, March, May and September (Fig. 2). The lowest B-GAL was recorded in May, while highest activity was recorded in November (Fig. 1). A difference of 2.5 fold in activity was observed between these two months. Sampling periods immediately after rainfall mostly yielded lower enzyme activities. A possible reason for this observation is that rainfall initially increases counts because of wash-off but dilutes the concentrations of coliform and E. coli in the water once 'wash-off' is completed. Sampling directly after a rain storm and sampling days after a rain storm could therefore influence results.

Contrary to the observation that a high level of faecal coliforms are observed after rain storms (Venter et al., 1997), results from these studies showed a decrease in enzyme activities that were positively correlated to the coliform counts. The enzyme

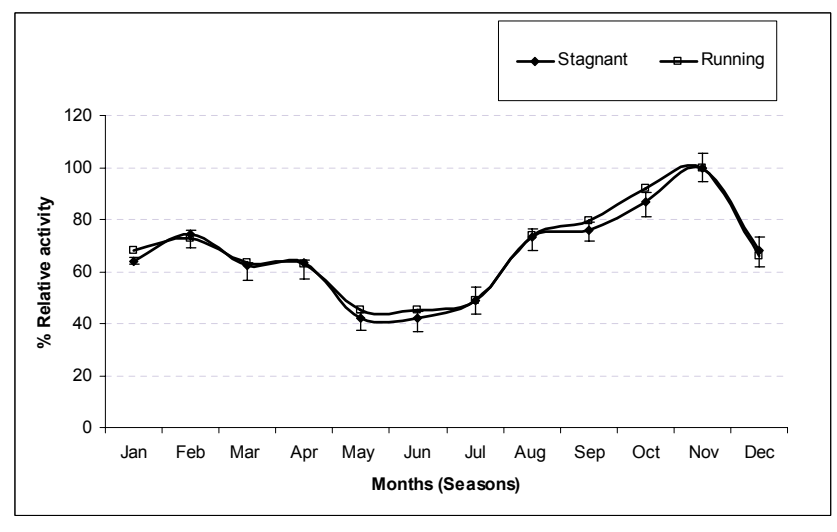

Figure 1

Relative monthly mean variation in B-GAL activity. $100 \%$ activity refers to maximum mean monthly activity. All values represent the mean $\pm S D,(n=3)$. 
Figure 2 Mean monthly GUD activity variations at the two study sites. All values represent the mean \pm $S D(n=3)$.

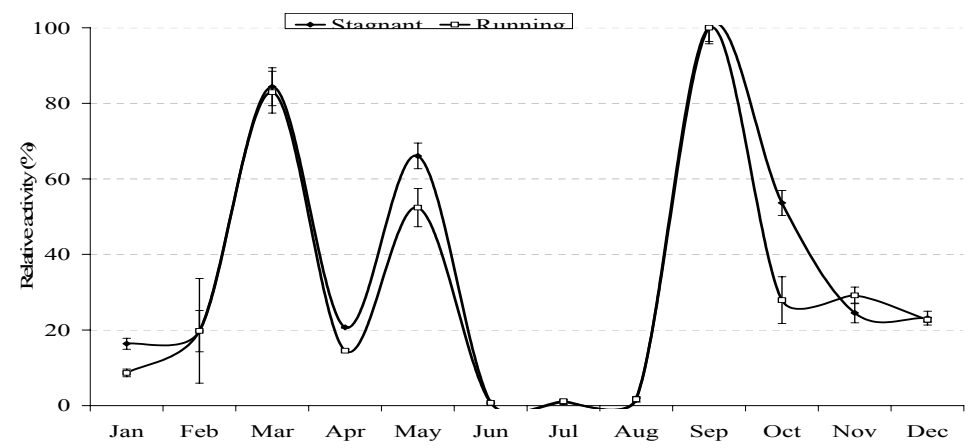

activity is partly a function of the amount of enzyme present and partly of inhibitor concentration. Low enzyme activity may also be attributed to a high level of enzyme dilution. Higher activity obtained during warm periods may be explained by high microbial activity under such temperatures and mixing aided by convection currents.

The monthly (seasonal) changes in the enzyme activity could be due to factors ranging from changes in domestic, agricultural and social habits. Livestock activities could also have affected enzyme activity.

Enzyme activity and quantity in aquatic environments varies by depth (Hoppe, 1991), time of day and season. Depth variations are influenced by the nature of occurrence of the enzyme. Some enzymes are immobilised onto sediments and settle on the river bed while others may be free floating, hence found throughout the water column.

\section{Annual variations in temperature and $\mathrm{pH}$}

The highest B-GAL activity in Fig. 1 coincided with the highest temperature as observed in Fig. 3. A variation in the $\mathrm{pH}$ of less than $0.2 \mathrm{pH}$ units was observed throughout the year (Fig. 3). Major determinants in daily and seasonal variations are temperature and volume of runoff. Warm temperatures (e.g. temperatures above $25^{\circ} \mathrm{C}$ ) enhance microbial growth, increasing enzyme production and activity. In addition, increases in temperature enhance the degradation of organic compounds thus providing nutrients for the microbes leading to more enzyme activity. Therefore, warm seasons may exhibit high enzyme activity and quantity. Increases in temperature also allow for the mixture of stagnant water bodies by convection currents.

During storms, runoff introduces allochthonous material into the water bodies. Depending on the quality and quantity of such material, enzyme activity and quantity may be enhanced or reduced. Such a variation has a bearing on the time of sampling and determination of faecal material. Human activities along the course of the river (e.g. washing and bathing) can also potentially affect the quantity and rate of enzyme activity.

\section{Regression studies and detection limits}

There was a positive correlation between total coliforms and BGAL activity, $\mathrm{R}^{2}=0.9151$ (Fig. 4), even though the CFUs were not evenly distributed. The extent of the linear relationship varies with location and degree of pollution of a water body. Correlations between total coliforms and B-GAL activity have previously been reported (Farnleitner et al., 2001; 2002). There was a significant $(\mathrm{P}<0.05)$ positive correlation between $E$. coli counts and GUD activity $\left(\mathrm{R}^{2}=0.89\right)$ (Fig. 5). The observed correlation coefficient $\left(\mathrm{R}^{2}=0.89\right)$ was better than the 0.73 previously reported by Farnleitner et al. (2001). Generally, it is difficult to

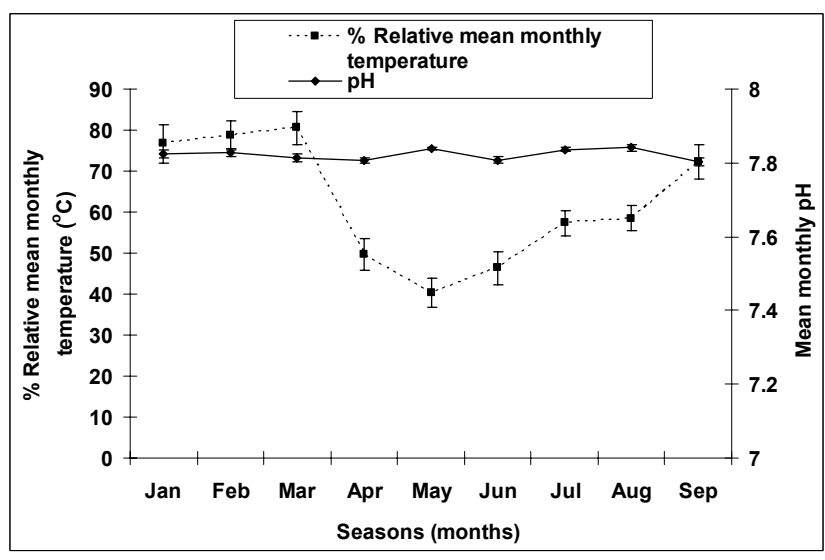

Figure 3

Annual variations in temperature and $\mathrm{pH}$. All values represent the mean $\pm S D(n=3)$.

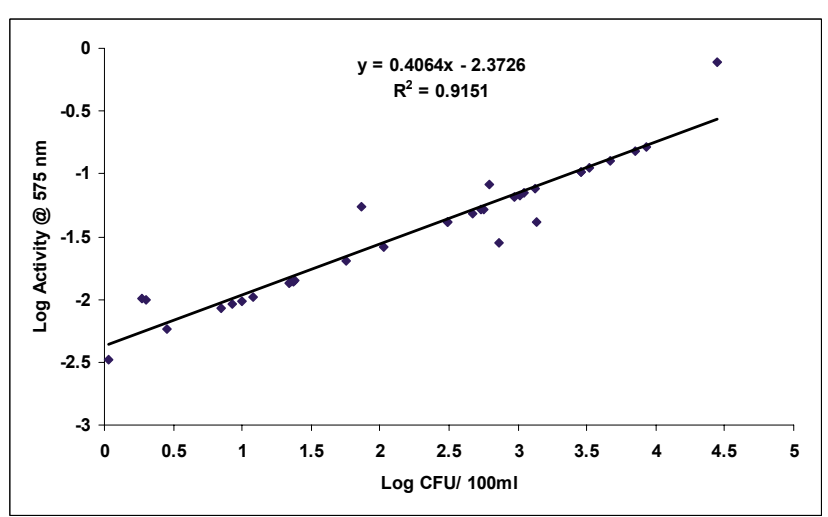

Figure 4

Regression analysis of B-GAL activity vs. total coliform colonyforming units (CFUs) for different water samples $(n=35)$

obtain a high correlation in different environments, considering the viable but non-culturable (VBNC) bacteria and their degree of viability that may vary with water pollutants and nutrient concentrations. However, correlation coefficient of above 0.8 suggests a positive correlation between the organisms in question and the activity of their respective marker enzymes. BGAL activity and microbial growth were observed on the plates in samples from river mouths and marine environment. The spectrometric limit of detection (LOD) of total coliforms was $1 \mathrm{CFU} / 100 \mathrm{~m} \ell$ and $2 \mathrm{CFU} / 100 \mathrm{~m} \ell$ for $E$. coli. While a result of $1 \mathrm{CFU}$ and $2 \mathrm{CFU} / 100 \mathrm{~m} \ell$ can indicate an extremely sensitive technique, one should approach these values with some caution because it does not necessarily mean that one or two CFUs are 


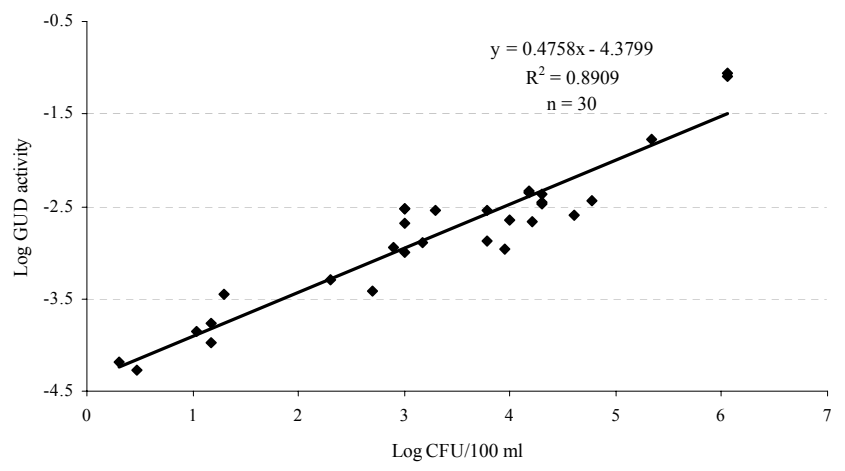

Figure 5

Regression of E. coli counts on GUD activity in environmental water samples $(n=30)$

entirely responsible for the observed activity.

The correlation between microbial counts and enzyme activities illustrates the degree of accuracy of the MF technique and the direct enzyme assays. If the two methods gave similar results with the same degree of accuracy then the correlation coefficient would be equal to one. However, the issue of detection of VBNC bacterial enzyme activity could potentially account for the deviation of $\mathrm{R}^{2}$ from 1 . The poor correlation between enzyme activity and CFU in marine samples highlights the possible limitation of using this technique in marine samples. On the other hand, the observation that B-GUD and B-GAL activities were present in all samples highlighted the ability of the direct enzyme assaying method to detect enzyme activity of VBNC cells. This makes the technique more favourable and potentially more applicable to marine environments.

When non-target micro-organisms producing GUD occur in high numbers, a sensitive GUD detection technique may be susceptible to interference. Van Poucke and Nelis (1997) highlighted the paradoxical nature of sensitivity of direct enzyme assay to the level as low as $1 \mathrm{CFU} / 100 \mathrm{~m} \ell$ of water sample. They argued that an increase in sensitivity is coupled with a concomitant increase in susceptibility to interference from non-target sources. While this is true, GUD and other enzymes from different sources normally are known to operate optimally at different $\mathrm{pH}$ values.

\section{Conclusions}

The amounts and activities of the marker enzymes in the environment are highly variable. Results from direct enzyme assays for the detection and enumeration of these marker enzymes as determinants of microbial water quality should therefore be stated with caution. Determination of coliform and E. coli numbers by direct enzyme assays may not give a true picture of the extent of pollution depending on the time of the year. Direct enzyme assays, however, were more sensitive than the MF technique.

\section{Acknowledgements}

The authors would like to thank the Water Research Commission (WRC) of South Africa and the Joint Research Committee (JRC) of Rhodes University for financial assistance during the course of this study.

\section{References}

AICH S, DELBAERE LT and CHEN R (2001) Continuous spectrophotometric assay for $\beta$-glucuronidase. BioTechnol. 30 846-850.

BERG JD and FIKSDAL L (1988) Rapid detection of total and fecal coliforms in water by enzymatic hydrolysis of 4-methylumbelliferone- $\beta$-D-galactopyranoside. Appl. Environ. Microbiol. 54 (8) 2118-2122.

FARNLEITNER AH, HOCKE L, BEIML C, KAVKA G and MACH RL (2002) Hydrolysis of 4-methylumbelliferyl- $\beta$-D-glucuronide in differing sample fractions of river waters and its implication for the detection of fecal pollution. Water Res. 36 975-981.

FARNLEITNER AH, HOCKE L, BEIWL C, KAVKA GG, ZECHMEISTER T, KIRSCHNER AKT and MACH RL (2001) Rapid enzymatic detection of Escherichia coli contamination in polluted water. Lett. Appl. Microbiol. 33 246-250.

FISHER KL and WOODS JP (2000) Determination of $\beta$-glucosidase enzymatic function of the Histoplasma capsulatum $\mathrm{H}$ antigen using a native expression system. Gene. 247 191-197.

HOLME DJ and PECK H (1998) Analytical Biochemistry ( ${ }^{\text {rd }}$ edn.). Longman, Essex.

HOPPE HG (1991) Microbial extracellular enzyme activity: a new key parameter in aquatic ecology. In: Chróst RJ (ed.) Microbial Enzymes in Aquatic Environments. Springer-Verlag, Berlin. 60-83.

PELISEK J, ARMEANU S and NIKOL S (2000) Evaluation of $\beta$ galactosidase activity in tissue in the presence of blood. J. Vasc. Res. 37 585-593.

SEEBER F and BOOTHROYD JC (1996) Escherichia coli beta-galactosidase as an in vitro and in vivo reporter enzyme and stable transfection marker in the intracellular protozoan parasite Toxoplasma gondii. Gene 22 (169(1)) 39-45.

STANDARD METHODS (1989) Standard Methods for the Examination of Water and Wastewater (1 $17^{\text {th }}$ edn.) American Public Health Association, Washington, DC.

VAN POUCKE SO and NELIS HJ (1997) Limitations of highly sensitive enzymatic presence-absence tests for detection of waterborne coliforms and Escherichia coli. Appl. Environ. Microbiol. 63 (2) 771-774.

VENTER SN, STEYNBERG MC, DE WET CME, HOHLS D, DU PLESSIS G and KFIR R (1997) A situational analysis of the microbial water quality in a peri-urban catchment in South Africa. Water Sci. Technol. 35 (11-12) 119-124. 